\title{
Co-enforcing Labor Standards: The Unique Contributions of State and Worker Organizations in Argentina and the United States
}

\author{
Matthew Amengual \\ Massachusetts Institute of Technology \\ MIT Sloan School of Management \\ Institute for Work and Employment Research \\ Janice Fine \\ Rutgers School of Management and Labor Relations \\ Department of Labor Studies and Employment Relations
}

April 11, 2016

Accepted. Regulation \& Governance

\begin{abstract}
:
Labor inspection is a central response to the tremendous gap between regulations on the books and outcomes for workers throughout the world. Scholarly and policy debates on labor regulation have focused attention on improving the targeting of enforcement, changing strategies of street-level agents, and creating private alternatives to state regulation. This paper argues that these proposals, while important, fail to systematically incorporate the potential contributions of worker organizations and, as a result, overlook opportunities for co-enforcing labor standards, a key element of labor inspection. By contrast, we develop a framework to analyze the relationships between worker organizations and state regulators that underpin co- enforcement. We ground this framework empirically in comparative cases, set in Argentina and the United States, presenting two cases of co-enforcement in highly different institutional contexts. By doing so, we seek to illuminate key attributes of labor inspection and guide attempts to enhance enforcement by forging partnerships between regulators and worker organizations.
\end{abstract}


The persistent gap between regulations on the books and outcomes for workers has revived interest in labor standards enforcement. Scholars have examined how differences in the organization of inspectorates and enforcement strategies improve standards and compliance. This research agenda has produced innovative analyses of labor inspection and proposals for enhancing enforcement. However, these analyses, and their related policy prescriptions, tend to focus on the state as isolated from civil society. While there is an older literature on labor organizations and enforcement, mainly in the European context, current debates in labor inspection have largely overlooked the existence and potential for partnerships between labor inspectors and worker organizations. ${ }^{[1]}$ This oversight has deprived scholars of tools to understand the relationships between these actors and, perhaps more importantly, has limited the range of policy options considered by reformers. In addition, it has segmented studies of labor inspection from the broader scholarly debates concerning regulation that have intensively explored collaboration across the state-society divide.

This article contends that co-enforcement-ongoing, coordinated efforts of state regulators and worker organizations to jointly produce labor standards enforcement - is an important, yet overlooked, mode of labor standards enforcement. We argue that to understand the potential for co-enforcement it is necessary to recognize two elements of enforcement - the nonsubstitutable capabilities of state and society, and the construction of political support for partnerships within both regulatory bureaucracies and worker organizations - both of which are obscured in dominant debates. By bringing the study of labor regulation back into discussions of collaborative regulation, we challenge scholars of labor inspection to take seriously the roles of worker organizations. In addition, we enrich the broader literature on collaborative regulation which has focused on managing the tensions between accountability and discretion, by 
demonstrating how societal groups that have strong ties with individuals that have knowledge of violations can contribute to the regulatory process.

Our study is based on an inductive and comparative analysis of cases of labor inspection in Argentina and the United States. It departs from most comparative regulation studies by focusing more on similarities than on differences. For instance, Kelman's (1981) classic study of occupational safety and health regulation in Sweden and the U.S. uncovered stark contrasts in enforcement approaches and inspector-union relations, which he attributed to differences in the institutions of the two countries. This and other comparative works have made important contributions by identifying a cornucopia of strategies for labor regulation (Piore \& Schrank, 2008; Coslovsky, Pires \& Silbey, 2011). By contrast, we use a comparative method not to identify novel regulatory strategies that align with institutional structures, but rather to explore a single regulatory strategy — coproducing enforcement with worker organizations—in the face of highly different institutional structures (Locke \& Thelen, 1995). In the United States, there is a rich history of independent regulatory agencies that has evolved into an organizational culture that views collaboration in enforcement as anathema. In Argentina, there is no history of regulatory independence, and legal structures — as well as political norms - give unions extensive access to the state, but unions generally suffer from weak shop-floor presence and legitimacy. By studying co-enforcement in both contexts, we follow Small's prescription of selecting a series of cases that provide distinct opportunities for evaluating a theory (Small 2009). Given the underdevelopment of the theoretical literature on coproducing labor standards enforcement, we believe that an inductive approach to theory building is more appropriate than sharp testing of hypotheses. 
This article is organized in four parts. The first reviews conventional responses to the crisis of labor standards enforcement. The second builds on the literature to offer an approach to labor standards enforcement that illuminates key aspects of co-enforcement that have otherwise been obscured. The third analyzes two cases - one in Argentina and one in the United States - to substantiate the claim that it is impossible to understand how enforcement occurs in these places without taking co-enforcement into account. The fourth discusses differences and similarities across the cases, further probing what conditions make co-enforcement function, as well as the particular political challenges to maintaining partnerships for enforcement in distinct political contexts.

\section{The Crisis of Enforcement}

Labor law enforcement in much of the world has been inadequate for countering the growth of a vulnerable workforce and the ensuing global reality of poor labor standards. A recent ILO report concluded that most of the world's inspectorates suffer from "insufficient staffing, inadequately trained personnel...” (International Labor Organization 2006, p. 116) an observation echoed by researchers studying a range of countries (Cooney, 2007; Bernhardt, 2009; Castillo-Reynoso, 1999; Anner, 2008; Bensusán, 2006). Simultaneously, the proliferation of intricate value chains has increased demands on inspectors (Weil, 2014). With few exceptions, such as Brazil and the Dominican Republic (Pires 2011; Schrank 2013), most countries' labor inspectorates have made few improvements in their ability to respond to these challenges.

Two kinds of proposals have been advanced in response to this crisis. One is a call for increasing the numbers of labor standards investigators and greater professionalization of the labor inspectorate (ILO Conventions $81 \&$ 129, 2006). Scholars have found a relationship 
between the size of inspectorates and compliance outcomes, arguing that deterrence gives rational firms incentives to comply (Ronconi, 2010). These proposals derive from the theory that enforcement intensity is directly related to capacity within state regulatory bureaucracies, commonly understood as Weberian organization and sheer heft (Berliner et al., 2015).

A second set of proposals rests on the theory that how inspectors work, rather than how many inspectors there are, determines the efficacy of enforcement. Weil (2010), for example, has called for employing "strategic enforcement" that targets highly non-compliant industries and takes advantage of industry-specific dynamics and structures to impact networks of interconnected employers. Studies of labor inspection in Latin America have also argued that when inspectors enforce regulation in a flexible manner they can reduce root causes of noncompliance (Piore \& Schrank, 2008; Pires, 2011).

\section{Coproduction and Collaborative Governance}

Both sets of proposals discussed above largely deemphasize the role of worker organizations. This oversight is somewhat surprising because multiple studies have shown that the presence of unions improves enforcement (Weil, 1991; Morantz, 2013). How can we analyze labor inspection in ways that take into account the possibility that workers can be more than passive victims and worker organizations can do more than provide arm's length political support for enforcement? One place to begin is to build on the "new regulatory" and "responsive regulation" scholars, who have called for systems whereby various actors, at times including workers, are involved in the regulatory process (Ayres \& Braithwaite, 1992; Bardach \& Kagan, 2002; Sabel \& Dorf, 1998; Estlund, 2010; Lobel, 2004; Freeman, 1997 \& 2000). Researchers have suggested a number of key elements of regulatory collaboration, including: clearly defined roles, ground rules, protocols, direct engagement in decision-making and process transparency 
that can ensure all parties of the ongoing procedural legitimacy of the partnership (Ansell \& Gash, 2008; Busenberg, 1999; Murdock, Weissner \& Sexton, 2005). For the most part, however, this research has focused on handling the tensions embedded in regulatory discretionspecifically addressing democratic deficits, engendering cooperation among firms and regulators, and avoiding capture. Perhaps the archetypal proposal in this arena is Ayres and Braithwaite's tripartism model, under which non-governmental organizations gain access to information, a seat at the negotiating table with the firm and agency, and the same standing as the regulator to sue or prosecute under regulatory statutes. Ayres and Braithwaite view tripartism as a way to "guard the guardians," and prevent regulatory capture by making guardianship contestable and optimizing the level of sanctions (Ayres \& Braithwaite, 1991, 440-441).

As we will show in the case studies below, however, the focus on guarding the guardians only partially encapsulates the dynamics of including societal groups in the regulatory process. In part, this is because, as we will show, societal groups can play both political and operational roles. To include this broader set of roles, we build on theories of coproduction, defined as "the process through which inputs used to produce a good or service are contributed by individuals who are not 'in' the same organization" (Ostrom 1996, p. 1073). In contrast to tripartism, in Ostrom's formulation of coproduction, politics are downplayed and the production function of implementation becomes the central element of the analysis. In our analysis, we seek to integrate the concept of coproduction into the regulatory governance literature by considering both operational challenges and the political underpinnings of solving them. To do so, we highlight two factors that are particularly evident in labor inspection and have broader implications for debates on regulatory governance: 1) the non-substitutable elements of state and society and 2) the construction of a collaborative political relationship between state regulators 
and worker organizations. For ease of understanding, we have decided to label the concept "coenforcement" rather than "coproduction" because we have found that the reference to "production" confuses those not intimately familiar with the literature.

\section{Non-Substitutable Elements of State and Society}

At first glance, studying co-enforcement with labor inspectors and worker organizations appears to be an exercise in mapping out an additive effect. Worker organizations, for example, might provide in kind support to inspectors in the form of transportation or translation. In these circumstances, enforcement itself is not materially changed, just augmented. Such inputs are important, but are largely "substitutable" (Ostrom, 1996). When regulators could provide the exact same "inputs" as worker organizations, more generous budgets for enforcement agencies or better strategies could easily increase "outputs" and substitute for collaboration with worker organizations. In this scenario, co-enforcement is helpful, but limited.

Worker organizations, however, potentially have resources that can only be partially substituted by the state and only at very high cost. Consider that enforcement begins with workers on the "shop floor" and that what workers are willing to share about what they see, hear, and experience firsthand is instrumental to identifying non-compliance. Workers have unique capabilities to enhance enforcement because they are present at the worksite every day, and have tacit knowledge of the work process, formal and informal teams and communication networks, and firsthand experience with changing working conditions and employer practices over time (Polanyi, 1967). Many worker organizations can tap into social networks which afford them vast amounts of information that would otherwise be difficult for state officials to gather alone (Hardy, 2011; Fine \& Gordon, 2010; Fine, 2014; Amengual, 2016). Worker organizations can also provide a safe space, interpretation and facilitation for meeting with workers intimidated by 
officials (Gordon, 2005; Weil \& Pyles, 2005; Fine, 2014). Building trust is key to gaining information about workplace violations and it is more likely to transpire through worker organizations, especially when deeply rooted in sociocultural or political communities (Gleeson, 2009). In addition, worker organizations play a political role in representing the interests of their constituents, and thus are able to advocate for enforcement within administrative structures in ways that bureaucrats, who must appear neutral to multiple principals, cannot.

State regulators also have unique capabilities and independent powers. The state is the monopoly holder of coercive powers that can be used to induce compliance. State regulators have the power to set standards, incentivize behavior, and compel firms to undertake improvements. They can also demand information, conduct on-site inspections of facilities and payroll records, and issue penalties, denial of licenses and firm shutdowns. The state can also protect complainants and informants from retaliation. Inspectors know the complexities of the laws they are enforcing and the procedures necessary to build strong cases. The state has the ability to empower groups, by delegating to them certain rights and privileges to enforce regulations (Ayres \& Braithwaite, 1992; Fine \& Gordon, 2010), both operationally and politically, where worker organizations are absent or weak. Finally, by targeting sectors, citing employers and publicizing their enforcement actions, the state also has the unique power to legitimize claims of workers and worker organizations to broader society (Gordon, 2005).

In sum, the non-substitutable elements of state and society are not reducible solely to improved strategies of regulators or increased capabilities of state bureaucracies, although these do matter. Moreover, these elements allow societal organizations to influence the operational tasks of enforcement itself, going beyond representation in negotiations that has been emphasized in the tripartism model. Recognizing non-substitutable elements reveals aspects of 
labor inspection otherwise obscured, and can allow enforcement efforts that take advantage of such capabilities. In contrast to government contracting with a third party to deliver a service previously in their purview, co-enforcement is intended to complement rather than replace government enforcement capacity.

\section{Political Support within Government, Bureaucracies and Worker Organizations}

The mere presence of capabilities in societal organizations does not mean that they will be mobilized for enforcement, nor will better organized or more strategic inspectorates automatically engage in co-enforcement. Co-enforcement is a departure from the norm in many regulatory contexts, and, as such, political support must be garnered and maintained within both state regulatory bureaucracies and worker organizations, as well as the general public. While elected officials have significant and necessary powers - to appoint or remove agency leaders, back them when they are under pressure, and push them when they are resistant, as well as to approve, reject, increase or decrease agency funding - their support alone is insufficient for coenforcement; thus, we cannot reduce political support to standard principal-agent models of political control over the bureaucracy (Moe, 1984, Cook and Wood, 1989, Miller 2005). Instead, co-enforcement must also be strongly supported internally by agency leaders because they have the power to legitimate, push for a shift in standard operating procedures within their organizations, and encourage investigators to collaborate and share information. Investigators, as street level bureaucrats, will always have the discretionary power to resist collaboration and cannot therefore solely be commanded but must also be persuaded and incentivized to participate in co-enforcement. As regulators and worker organizations collaborate in the process of enforcement, they necessarily cede some control over tasks and decisions that were once entirely within their purview. More broadly, regulators face the risk of being branded as "anti-business" 
or biased, acting in the interest of worker organizations instead of the public good. These possibilities make collaborations especially politically sensitive, requiring support both externally and internally.

While the coproduction literature, including Ostrom's (1996) original formulation, has been attentive to the political challenges of the state, the dilemmas worker organizations face when coproducing enforcement have not been fully explored. To begin, worker organizations must accept the premise that cooperation with a government agency is more efficacious than pursuing their own separate, and often more adversarial, strategy; they must overcome prior negative experiences and the mistrust of their members and sacrifice gains, such as increased attention from the media and elected officials, that may come from a more adversarial approach. Once having entered into partnership, the organization is often compelled to embrace a less aggressive strategy in order to allow the regulatory agency to conduct an investigation and pass its own judgment on the severity of a case and appropriate penalties. Maintaining support for collaboration thus requires worker organizations to accept the limitations of government agencies and modulate the demands they make on them, particularly with respect to speed and information sharing, while also investing time and resources into the enforcement process. Critically, they must provide external political support for enforcement resources, not only for the collaboration but for the agency itself.

In sum, analyzing support within labor inspectorates and worker organizations for coenforcement reveals important elements of enforcement overlooked in the literature. Theories of labor standards enforcement that focus on the heft of bureaucracies and their direct deterrence efforts often focus simply on hiring more inspectors and reduce the role of politics to being for or against aggressive enforcement (Ronconi, 2012). In fact, theories focused on approach and 
strategies for enforcement generally ignore politics, assuming that the key problem is getting regulatory agencies enough autonomy to adopt preferred strategies. Neither of these theories, however, speak to the willingness of regulators to cede some of their autonomy to worker organizations, which inevitably occurs in co-enforcement. We contend, by contrast, that external and internal political support for partnerships is not reducible to support of enforcement generally.

\section{Examples of Partnerships}

In this section, we recount examples of co-enforcement from Argentina and the United

States. ${ }^{[2]}$ Notwithstanding the distinct politics, histories, and institutions in these two countries, many similarities exist in the dynamics of enforcement Within each country, we purposefully selected cases that exhibited strong elements of co-enforcement, an appropriate strategy as we do not seek to gauge the average effect of co-enforcement on compliance, but instead seek to understand how it challenges to the dominant theories of labor standards enforcement (Collier \& Mahoney, 1996; Small 2009). The cases support our contention that analysis beyond labor inspectorates' heft and strategic orientation provides new insights into their functioning, and illustrates how responsive regulation with labor does more than guard the guardians.

\section{Health and Safety Regulation in Construction: Córdoba, Argentina}

Labor inspection in the Argentine province of Córdoba has struggled to keep up with changes in the economy over the past 20 years. ${ }^{[3]}$ One exception is the health and safety division, CYMAT (Condiciones y Medio Ambiente del Trabajo) of the Labor Secretariat (Secretaría de Trabajo de Córdoba, STC), that regulates the construction industry. During the commodity boom that followed the economic crisis in 2001, the number of registered construction workers in Córdoba swelled from 1,600 in 2004 to 20,000 in 2005, and to nearly 
30,000 by 2008 . Growth was accompanied by heavy reliance on subcontracting and temporary firms that dissolved as projects were completed $(\mathrm{C} 15,2009)$. The combination of rapid expansion and change in firm structure brought a sharp increase in the risk of accidents (C32, 2008 \& 2009), which CYMAT has met with notable enforcement.

A key feature of enforcement in the construction industry is formal and informal interaction between the union, inspectors, and industry, an arrangement that goes back to the end of the military dictatorship in 1983. In 1987, union leaders took steps to "punish the government, the firms, and the industry association" for the lack of safe working conditions. As a result of the "crisis" generated by this action, "the government felt pressure" to do something about accidents $(\mathrm{C} 17,2008)$ and the labor minister created the CYMAT as a special division, laying the foundation for ongoing state support for health and safety.

The minister also "called for the social actors to get together in conversation and meeting" $(\mathrm{C} 17,2008)$. These meetings involved officials from the STC, the construction workers' union, UOCRA (Unión Obrera de la Construcción de la Republica Argentina), and the industry association, and eventually led to the formation of a formal consultative Commission that became a forum for dialogue in the industry (La Voz del Interior, 2004). UOCRA's health and safety officer was in daily touch with his counterparts in the inspectorate, and UOCRA leaders actively worked to build this relationship, hosting a barbecue with inspectors a few times a year to "unite" the parties around common goals (C32, 2008 \& 2009). This type of fluid relationship between unions and inspectors is typical of Argentine provinces where there is a political alliance between the party in power and the unions.

The resulting continuous flow of information and resources enabled inspectors to leverage the capacities of their union counterparts. Inspectors gained a substantial amount of 
information about working conditions in the industry through UOCRA's extensive network of delegates and teams dedicated to safety, and had access to union cars and political support. The head of health and safety inspection stated: "We complement one another. When the unions have a problem, we advise them... and they...come with the cars... which they put at our service so we can complete our objectives and conduct inspections" $(\mathrm{C} 44,2008)$.

Complementing UOCRA's contributions, CYMAT used its own resources to inspect workplaces where UOCRA lacked presence. A senior CYMAT official explained that "if I had to wait for UOCRA to accompany the inspections, we would only do 1,000 inspections [a year]" (C22, 2008 \& 2009). Instead, CYMAT took the initiative and conducted well over 2,000 inspections annually. ${ }^{[4]}$ When plans for a new construction site exceeded a minimum size, CYMAT regulators conducted an initial inspection to ensure that construction plans included health and safety considerations. CYMAT also received tips about worksite accidents from the national Superintendent of Workplace Risks and from the wage and hour inspectors (C36, 2008).

Using this confluence of information, regulators put together programmed inspection campaigns that were both preventative and responsive to immediate risks. The union's health and safety leader described how they worked with inspectors: "When there is a particular zone that has high risks, we go together. Or when we hear that things are messed up in a certain place, we work together," otherwise they took care of the problem themselves $(\mathrm{C} 32,2008$ \& 2009). UOCRA's strategy recognized the fact that the state had allocated resources to regulate construction and granted inspectors leeway to conduct inspections independently: "the inspectors have a list of construction sites that comes from above. We know that they have to [make] progress in making it through this list of sites, so we don't call them except when we know that there is a problem" (C32, 2008 \& 2009). Thus, UOCRA's leaders modulated their demands and 
maintained political support within the union to keep the partnership going. This strategy contrasted with that of many Argentine unions and worker organizations that bombarded the inspectorate with requests and prevented any strategic planning (Amengual 2016).

When conducting inspections, CYMAT was able to take both punitive and pedagogical actions. In the construction industry, suspensions of unsafe workshops are the most important penalties because they impose immediate and high costs (unlike fines, which can be appealed and are often minimal). A business leader observed that "when the inspectors shut down a worksite, it causes a lot of pain " for the construction firm in terms of lost time and money (C15, 2009) ${ }^{[5]}$ CYMAT inspectors exercised their power, to unilaterally shut down, or suspend, operations. In 2004, for example, accidents began to increase and UOCRA publicly criticized CYMAT for not being tough enough on violators (La Voz del Interior, 2004). The inspectors responded by drastically increasing suspensions of construction sites that posed an immediate danger to workers. Prior to UOCRA's criticism, inspections resulted in suspensions $1.6 \%$ of the time; in the month afterwards, this number increased to $19 \%$. Inspectors later adjusted to mixing penalties with other approaches: in 2007 and 2009, inspections resulted in partial closures of construction sites $10 \%$ of the time, and full suspensions $4 \%$ of the time. Thus, even though UOCRA and regulators collaborated and UOCRA modulated its demands in some ways, the union maintained the ability to hold regulators accountable.

Penalties are rarely enough to improve compliance on their own, especially for health and safety standards. Accordingly, when CYMAT inspectors found problems that did not pose an immediate risk, they offered advice to construction managers and workers on how to comply. For example, on one construction site, health and safety inspectors instructed managers on identifying and alleviating conditions that lead to workers falling off buildings (e.g., putting 
plywood barriers) which helped managers and workers anticipate new risks on worksites (C35, 2008; C36, 2008). ${ }^{[6]}$ Beyond this, CYMAT and UOCRA have systematically taken steps to prevent accidents. A senior official in the STC described an example:

We have designed training days in the worksites... representatives of the STC and UOCRA go, and on the day of the training, the firm changes the work schedule so that we can meet with all of the workers and managers. Two of my inspectors talk specifically about what workers are doing (on the site) and what health and safety measures they should take in a practical way (C22, 2008 \& 2009).

For union leaders, these in situ trainings were a "valuable" way of reducing accidents in the long run and addressing the root causes of violations (C32, 2008 \& 2009). In 2009, the mixture of real penalties plus training made Córdoba an example of best practices in regulation, unmatched elsewhere in Argentina (Ayres \& Braithwaite, 1992; Pires, 2008). Notably, the number of accidents did not increase with the substantial increase in workers, which union leaders and officials view as an indicator of successful enforcement $(\mathrm{C} 32,2008 \& 2009) .{ }^{[7]}$ While there were certainly limitations - union leaders have not reached their goal of eliminating accidental deaths and inspectors would prefer to have more resources to increase inspections-the relative level of enforcement in construction was high when compared with the same industry in other provinces of Argentina.

If this case was analyzed either as an attempt to fortify the internal organization of the inspectorate or improve the strategy of regulators, many developments crucial to strengthening enforcement would be missed. First, important capabilities in the state and in the union differed from one another. Second, thick ties between inspectors, unions, and even businesses allowed for these capabilities to be combined in productive ways through information sharing and on-site training. Third, the way UOCRA modulated its demands, understanding the agency's needs, allowed CYMAT inspectors to utilize their expertise and allowed for greater diversity of targeting techniques. Finally, the politics of enforcement extended beyond general support for 
action by the bureaucracy and included support for the collaboration itself.

Local Labor Standards Enforcement: San Francisco

Established in 2001 largely through the efforts of the building trades unions, the first municipal labor standards enforcement agency in the United States, the San Francisco (SF) Office of Labor Standards Enforcement (OLSE) is responsible for an expansive set of local labor laws. The agency has powers to conduct investigations, initiate civic actions, involve the City Attorney in pursuing criminal cases, conduct joint investigations with the State, and request that city departments suspend or revoke licenses. As of 2014 , it had a budget of $\sim \$ 4$ million and 22 staff, including 18 investigators. Its creation augmented increased government resources at the local level to raise the probability that violators would be penalized for their actions.

Enforcement efforts went well beyond the establishment of a strong local inspectorate when, in 2006, the Board of Supervisors mandated the establishment of a community-based program to "conduct education and outreach to employees" (SF Administrative Code, Section 12R.25). OLSE was not involved in the decision to establish or fund the program (called the Collaborative), which grew out of conversations between advocates and members of the Board of Supervisors who viewed the organizations as playing a major role in improving conditions for low wage workers in the city. The organizations, many of which worked with the Board to strengthen the OLSE, saw the program as a way to help fund and expand their work (Ronen, 2014). Thus, since 2007 the agency has contracted with organizations including La Raza Centro Legal, Asian Law Caucus, Chinese Progressive Association, Filipino Community Center, Young Workers United, Pride at Work and Delores Street Day Laborers Center. Total funding has grown from just $\sim \$ 200,000$ per year to $\sim \$ 750,000$. The organizations in the Collaborative have 
been instrumental in lobbying for increased funding both for OLSE as well as for the Collaborative.

Worker organizations sign yearly contracts that require them to engage in outreach activities, worker trainings on municipal labor laws, and one-on-one consultation and referral services. Organizations are also expected to provide assistance in filing and screening complaints, and to attempt to bring employees and employers together to solve the problem. Organizations are also required to abide by certain protocols: membership recruitment, fundraising and workplace organizing are prohibited as is collection and use of personal information beyond that needed to meet contractual obligations. OLSE investigators accept documentation from the groups and work cases and participate in quarterly meetings.

One of the organizations central to the collaborative and instrumental in its lobbying efforts is the Chinese Progressive Association (CPA). In 2010, the CPA conducted a survey of working conditions in Chinatown, finding extensive wage, hour, and benefits violations (Nong et al., 2010). To combat them, the organization has a wage clinic funded through the collaborative that counsels workers on their rights and helps them file claims. In addition, worker leaders conducted outreach to educate workers about wage theft--handing out fliers at bus stops and leading workshops at community fairs and local community colleges.

In late 2009, CPA was instrumental in uncovering a major wage theft case at Dick Lee Pastry (Levitt, 2014, p. 11). Working together, CPA and OLSE investigators found that for nearly four years, seven Dick Lee employees had not been paid minimum wage, overtime or double time compensation as required by law, and that the company had falsified payroll records. Workers had been working six days per week on shifts of 11-14 hours, receiving "semi-monthly" wages of approximately $\$ 550$, averaging between $\$ 3.02$ and $\$ 3.91$ per hour. Dick Lee owners 
sought to obstruct the investigation and retaliated against workers who cooperated with OLSE by reducing their hours and firing one of them. Charging that these actions constituted unfair and unlawful business practices, the City Attorney sued the company for more than $\$ 440,000$ in wages and interest and eventually recovered $\$ 525,000$ including penalties (Herrera News Release, 2011). OLSE investigator Linshao Chin, a former CPA staff member, praised the unique capacity to build trust and gain information that CPA demonstrated in this and other cases: "All the initial intake work they do is so critical because it takes a lot to build trust with the workers, to get them to a place where they understand why it is important to collaborate with different government agencies and to even fill out the form or file a claim.... It takes organizing and education to get the worker to finally say 'I will fill out this claim form and put myself on the line..." (Chin, 2014, p. 2).

Chin described another case involving minimum wage violations and payroll falsification, Yank Sing, in which CPA, following more than a year of relationship building with workers through home visits and one-on-one meetings, persuaded more than ninety workers "who previously didn't trust the government agency and wouldn't talk to investigators" to file claims. (Chin, 2014, p. 5). The result of this joint work by CPA, OLSE and the state was a $\$ 4$ million settlement with back of the house workers collecting between $\$ 30,000-60,000$ each, the largest restaurant minimum wage settlement OLSE had ever been involved in and the largest settlement of any kind for a non-chain restaurant. CPA separately negotiated a "workplace change agreement" that included wage increases for kitchen workers, paid holidays, and an increase in paid time off and sick leave and other improvements (Liu, 2014; Herrera News Release, 2011). 
Another Collaborative member is the Filipino Community Center (FCC). Filipino immigrant workers are isolated in small care-home facilities where they also reside. Through numerous social and cultural activities, FCC was able to tap into social networks and get to know the workforce. What they found was a shockingly under-regulated industry. Workers were responsible for washing, dressing, medicating and feeding multiple patients throughout the day. They told of working with patients with severe dementia and mental health problems who sometimes became violent, of seldom being able to get more than a few hours of uninterrupted sleep, and the impossibility of being compensated for all the hours they worked. Recruiters and placement agencies were often part of an oppressive system that placed workers in facilities that paid below minimum wage and illegally deducted housing and food expenses.

Receiving OLSE funding enabled FCC to educate and organize workers, advocate for changes and file wage claims (Valen \& Pichay, 2014, p. 6). Through FCC, OLSE was able to reach a new constituency and has won many cases for caregivers, recovering over $\$ 1$ million in unpaid wages. "FCC has done fabulous work organizing the homecare workers... at this point we have done audits and recovered back wages in about ten residential care homes, most of them brought by FCC, ” said OLSE Director Donna Levitt. “Their campaign has been very creative-from doing door-to-door outreach to holding community events like ballroom dancing... These are cases we would not have gotten for the most part... and they build over time." (Levitt, 2014)

The collaboration has been maintained despite tensions between some OLSE investigators and some worker organizations. "Members of the collaborative naturally want to build their organizations and often push for a bigger role in negotiations...." Levitt (2014) says groups often call wanting to know the status of the case, "but once they bring us the claimant, and we meet with them, we will be communicating with the claimant rather than the community 
group. " One advocate said that the organization sometimes hesitated to refer cases to OLSE because "they are going to take over the case and I will be kept in the dark. Not only will I be, but the worker will be too, because their objective is to represent the City-you are wronging the City by not paying the worker-versus 'you are damaging the worker, let's do what we can for the worker." This sentiment was expressed by many of the organizations in the Collaborative. In interviews, a few investigators questioned the entire premise of the Collaborative, arguing that providing money to organizations risked compromising the agency's neutrality. Some expressed the view that organizations used cases as a way to bring about broader policy change, which they did not see as an appropriate use of City funding. Some argued that the groups did not warrant the frequent updates they were demanding. A few felt that, given their own personal backgrounds, they were just as capable of understanding and developing relationships with workers, and resented any suggestion that they were "outsiders". Some felt strongly that after a referral had been made to OLSE, it was inappropriate for groups to continue organizing and pressuring the employer. Finally, some OLSE staff said that they were disappointed that despite the financial support, the number of claims filed per year had not increased (Levitt, 2014, p. 7). Very few investigators expressed the view that strengthening the organizations by providing financial support was a good in and of itself.

For their part, the organizations were positive about working with OLSE, and appreciative of the funding, but some voiced concerns that investigators were sometimes too quick to dismiss cases brought to them and that the agency did not have written protocols regarding which cases to accept and how investigations would be carried out. Likewise, groups wished that more of the investigators were interested in partnerships, that they would provide more frequent updates about the status of cases and involve the groups more in settlement 
conversations with employers. In 2014, the parties agreed upon a revised set of contract requirements that stipulated, among other things, that each worker organization would resolve or refer to OLSE at least five labor law complaints each quarter. OLSE also appointed a different investigator, one more positive about the collaboration and conciliatory in his approach, as liaison to the organizations.

Finally, there has been some resentment at OLSE about the Collaborative's willingness to lobby for changes in policy unilaterally, by going to the Board of Supervisors without consulting the agency. The organizations may be taking this step in part due to the absence of a collaborative governance process. Going around the OLSE is also a consequence of political dynamics in city government. Although established by the Board of Supervisors, OLSE is located within a city agency and the Labor Standards Enforcement Officer is appointed by, and serves at the pleasure of, the Mayor. Although the agency's funding has not kept pace with its expanding mandate, Levitt is not allowed to lobby the Board of Supervisors directly for more money (Levitt, 2014, pp. 10-15). She is expected to work through the mayor's office. However, there is mayoral ambivalence about the labor mandates due to concerns about how they will affect the business climate. The Collaborative has been instrumental in increasing the agency's budget and OLSE acknowledges its important role in mobilizing political support from the Board of Supervisors to increase the budget despite the administration's general lack of enthusiasm for the program. As an indication of the strength of the Collaborative's political influence, although both the SF Chamber of Commerce and the Golden Gate Restaurant Association opposed the labor mandates and the enforcement initiatives, they had little impact.

This case reinforces the usefulness of co-enforcement and the two elements of regulatory enforcement set forth above as a theoretical framework for understanding the challenges that 
have emerged. However, despite SF's groundbreaking labor and employment policy mandates, unique local labor standards enforcement agency, and dynamic organizations funded to engage in enforcement, tensions persisted. Some investigators simply did not recognize the organizations' unique or non-substitutable capabilities contributing to enforcement. Others agreed there was value in the work the organizations were doing, but not enough to fundamentally alter their opposition to sharing information. There was also no formal agreement or set of protocols regarding how the partners would work together and no full-time staff dedicated to actively facilitating relationships in the Collaborative. Surprisingly, despite strong political support for the Collaborative, discord between government investigators and civil society groups posed challenges to deepening and strengthening co-enforcement on the ground.

Fundamentally, the success of co-enforcement depends upon strong relationships between the agency and workers (O'Rourke, 2004, p. 225), worker organizations and high road firms. Political support by the Board of Supervisors was indispensable to establishing the coenforcement regime, but internal agency support is needed for successful implementation. In reviewing the literature, Ansell and Gash (2008, p. 554) find that only in rare cases do negotiations take place without assistance; in most cases collaborative governance requires leaders on both sides who believe strongly in the project, prioritize the relationship, bring stakeholders together, set and maintain clear ground rules, build trust, facilitate dialogue, explore mutual gains and work together in a collaborative spirit. These leaders are especially important in situations where the incentives for participation are weak, power and resources are asymmetrically distributed or prior antagonisms between the actors are high.

\section{Structural Differences Condition Collaboration}


The cases above detail how regulators responded to the challenge of a high degree of subcontracting and poor compliance with labor law. Although operating in highly different political and social contexts, the similarities in the enforcement dynamics in both cases stand in striking contrast to standard accounts of labor standards enforcement. This section highlights key similarities and differences across the cases that refine our argument about the features of enforcement crucial to analyze how regulators and civil society organizations creatively navigate their institutional environments.

In Argentina, labor relations are highly corporatist, unions are given standing and certain governance tasks are devolved to them. Alternatively, the United States has a history of relatively weak, pluralist, unions who, for the most part, are not involved in carrying out functions traditionally under the purview of the state. These structural differences were not, however, decisive. Rather, formation and efficacy of partnerships resulted from regulators' strategic actions, supported by politically appointed officials, and worker organization investment in developing relationships. Notwithstanding the vast differences between UOCRA and the Collaborative, both organizations had capabilities that complemented the state. UOCRA is a national level union that runs a multi-million dollar health insurance fund and enjoys the exclusive right to negotiate sector-wide collective bargaining, while the Collaborative is a coalition of worker centers and non-profit legal aid organizations, who do not have any formal rights or official status in the labor market. Yet, both UOCRA and organizations in the Collaborative gained access to information by virtue of their relationships with workers and organizational staff who conducted checks on workplaces in ways that inspectors do not. Inspectors in both cases possessed formal authority to take legal action, like suspending operations on a construction site or collecting strong penalties in addition to back wages, that the 
worker organizations lacked. This similarity is non-trivial because of the distinct informal attributes of the enforcement agencies; in Argentina, as in many countries, labor inspectorates tend to lack authority in the face of politicization and corruption, while strong professional norms and a history of administrative neutrality prevail in the U.S.

Despite the similar outcomes, regulators and worker organizations in each place had to navigate vastly different institutional contexts even as they pursued similar ends. One key difference between the two cases was the availability of the state-union partnership model itself. In Argentina, where this model has been in place since the late 1940s, structures for collaboration and cultural familiarity with the model within the agency help to facilitate its adoption. Argentine law specifically grants unions the right to accompany labor inspectors, though this law is not always applied uniformly, and in some provinces informal steps are taken to reduce union involvement (Amengual 2016). Thus, even with formal institutional supports, in Argentina political struggles are necessary to foster real partnership. In the Córdoba case, action by the union led to a formal consultative commission that became a forum for the key stakeholders to strategize and make decisions, which was crucial to proactive efforts in worker training.

In the US, there have been very few explicit state-worker organization partnerships, and models that do exist are largely unknown (Gleeson 2009, Fine \& Gordon, 2010; Fine, 2014). Government agencies in the US tend to be very uncomfortable with formal partnerships with worker organizations, worrying that formalizing a relationship with a worker organization would jeopardize the perception of neutrality. Although there were quarterly meetings between the groups and OLSE, this was not a structured forum in which there were clear ground rules, protocols and joint decision-making processes in place. This discomfort with partnership has yet 
to be overcome in SF; its foreignness to the investigators and lack of experience with it has strongly discouraged its adoption even when codified into law. To date, the most effective relationships in SF are anchored by people who have experience working on both sides of the state/civil society divide: as organizers or advocates and investigators.

In sum, each political system had distinct challenges - one enactment of formal rules, and the other adoption of them - that needed to be overcome for co-enforcement to take hold. These differences shine a spotlight on the centrality of institutional design to co-enforcement in both countries, albeit in different ways. As the broader literature has suggested, clear role definition, ground rules, protocols, direct engagement in decision-making and process transparency can ensure all parties of the ongoing procedural legitimacy of the partnership (Ansell \& Gash, 2008; Busenberg, 1999; Gunton \& Day 2003; Murdock, Weissner \& Sexton, 2005; Rogers et al, 1993). The contentious politics of labor standards enforcement brings these characteristics into relief, leading us to concur with scholars of collaborative governance more broadly that formalization is important (especially in contexts in which co-enforcement is far outside of the norm) (Fung \& Wright 2001, 2003; Imperial, 2005; Weech-Maldonado \& Merrill, 2000; Ansell \& Gash, 2008).

\section{Conclusion}

This paper makes three principal claims. First, we argue that co-enforcement is a sensible policy response to the crisis of enforcement distinct from those that dominate the debate on labor regulation. While there are clearly boundary conditions on where co-enforcement can occur - there need to be some worker organizations and some state regulators - a growing body of evidence suggests that labor inspectors and worker organizations combine in powerful ways in countries as diverse as Australia, China, and Sweden (Hardy, 2011; Chung, 2013; Kelman, 1981). Further research should probe the boundary conditions and efficacy of co-enforcement 
arrangements. Second, we proposed two elements - non-substitutable capacities and political support internal to worker organizations and regulatory agencies - that must be taken into account to analyze enforcement partnerships. By doing so, we seek to correct oversights in the broader literature on labor standards enforcement that have prevented researchers from discovering instances of co-enforcement. Third, we use an underutilized comparative method that suggests that routine interaction between inspectors and worker organizations does not only depend on macro legal, institutional, and historical conditions. Through analysis of these highly different contexts, we are able to isolate the key dynamics of enforcement partnerships operating at the meso-level—between the macro or structural variables (e.g. corporatist or pluralist institutions, histories of administrative neutrality) and the micro strategies of individual inspectors. It is at this level where there are abundant opportunities for creative action by regulators and worker organizations and where substantial analytical leverage can be found.

Our work also makes broader contributions to the literature on coproduction and responsive regulation. Most centrally, we examine partnerships between regulators and worker organizations, which have tended to be overlooked in the literature that, despite its history, has recently only rarely included analyses of labor. Bringing in worker organizations has allowed us to show the key operational contributions of societal groups when they have access to information that can only be gained with the trust of workers with direct knowledge of working conditions. Thus, the role of non-governmental organizations becomes more than guarding the guardians; instead, societal groups take actions that the guardians are incapable of doing themselves. In doing so, we elaborate upon Ostrom's (1996) original argument about the need for participants to build a credible commitment to one another and find support for Ansell and Gash's argument that collaborative governance requires a collective decision-making process 
that is formal, consensus-oriented and deliberative (Ansell \& Gash, 2008, p. 544). In this way, our focus on operational tasks of regulation is not at the expense of politics, instead we demonstrate the importance of integrating the political and operational. The worker organizations we studied emphasized the necessity of collaboration and timely information sharing but did not always explain to the agencies that knowing the status of the case as it was progressing was essential for them to maintain credibility with workers and continue to expand cases. Government agencies emphasize that the organizations needed to understand and adapt to the pressures and constraints of their operating environment and have the capacity to add real value to investigations, but did not always say this directly to the groups. Our analysis suggests that managing such tensions is central to the politics of regulation, and can unleash or undermine co-enforcement.

We conclude by suggesting that the strengths of enforcement partnerships can augment many of the dominant policy proposals, such as increasing inspectors, undertaking more strategic enforcement, and experimenting with new regulatory techniques. Each of these approaches can be designed in specific ways to enhance the unique capabilities of, and explore possibilities for creating thicker ties among, state regulators and worker organizations. For example, inspectors can be explicitly encouraged to develop partnerships with worker organizations in non-compliant sectors and given tools that enable them to navigate the tricky politics of co-enforcement. We contend that in order to achieve effective industry-level action, strategic enforcement approaches should also experiment with leveraging partnerships with civil society organizations so that those who are closest to the action, possess the most information, and have the greatest incentives to partner with government to enforce the law, are fully engaged. Similarly, efforts to improve the capacity of worker organizations can focus on their unique capabilities and seek opportunities to 
strengthen their organizations while promoting enforcement. By combining various approaches with co-enforcement, policy makers and worker advocates will be positioned to utilize a broader range of tools to confront the challenges of enforcement. 


\section{Bibliography}

Aldrich, H \& Herker, D. (1977). Boundary Spanning Roles and Organization Structures. The Academy of Management Review. 2(2), pp. 217-230.

Amengual, M. (2010). Complementary Labor Regulation: The Uncoordinated Combination of State and Private Regulators in the Dominican Republic. World Development. 38(3), pp. 405-414.

Amengual, M. (2016). Politicized Enforcement in Argentina: Labor and Environmental Regulation. New York: Cambridge University Press.

Anner, M. (2008). Meeting the Challenges of Industrial Restructuring: Labor Reform and Enforcement in Latin America. Latin American Politics \& Society. 50(2), pp. 33-65.

Ansell, C. \& Gash, A. (2008). Collaborative Governance in Theory and Practice. Journal of Public Administration Research \& Theory. 18(4), pp. 543-571.

Asbed, G. \& Sellers, S. (2013). Fair Food Program: Comprehensive, Verifiable and Sustainable Change for Farmworkers. University of Pennsylvania Journal of Law \& Social Change. 16(1), pp. 1-10.

Ayres, I \& Braithwaite, J. (1991). "Tripartism,: Regulatory Capture and Empowerment" Law and Social Inquiry, Vol. 16, No. 3, pp. 435-496.

Ayres, I. \& Braithwaite, J. (1992). Responsive Regulation: Transcending the Deregulation Debate. Oxford: Oxford University Press.

Bardach, E. \& Kagan, R. (2002). Going by the Book: The Problem of Regulatory Unreasonableness. New Jersey: Transaction Publishers.

Bartley, T. (2007). Institutional Emergence in an Era of Globalization: The Rise of Transnational Private Regulation of Labor and Environmental Conditions. American Journal of Sociology. 113(2), pp. 297-351.

Beach, L. R. \& Mitchell, T. R. (1978). A Contingency Model for the Selection of Decision Strategies. Academy of Management Review. 3(3), pp. 439-449.

Bendor, J., Taylor, S. \& Van Gaalen, R. (1987). Stacking the Deck: Bureaucratic Missions and Policy Design. The American Political Science Review. 81(3), pp. 873-896.

Bensusán, G. (2006). Diseño Legal y Desempeño Real: Instituciones Laborales en América Latina. Universidad Autonoma Metropolitana Unidad Xochimilco Coordin. 
Berliner, D., Greenleaf, A., Lake, M. \& Noveck, J. (2015). Building Capacity, Building Rights? State Capacity and Labor Rights in Developing Countries. World Development. 72, pp. 127-139.

Bernhardt, A. D. (2009). Broken Laws, Unprotected Workers: Violations of Employment and Labor Laws in America's Cities. Center for Urban Economic Development, the National Employment Law Project, and the UCLA Institute for Research on Labor and Employment.

Bernhardt, A., McGrath, S. \& DeFilippis, J. (2008). The State of Worker Protections in the United States: Unregulated Work in New York City. International Labour Review. 147(2-3), pp. 135-162.

Busenberg, G. (1999). Collaborative and Adversarial Analysis in Environmental Policy. Policy Sciences. 32(1), pp. 1-11.

C15, Argentine Construction Association (CAC). 2009. Interview with the Author. 3 March, Córdoba.

C17, Construction Workers' Union of Argentina (UOCRA). 2008. Interview with the Author. 15 July, Córdoba.

C22, Senior Official, Córdoba Labor Secretariat, Córdoba. 2008 \& 2009. Interviews with the Author. 23 June 2008, 5 March 2009 \& 7 March 2009, Córdoba.

C32, Health and Safety Specialist, Construction Workers' Union of Argentina (UOCRA). 2008 \& 2009. Interviews with the Author. 20 June 2008 \& 9 March 2009, Córdoba.

C35, Health and Safety Inspector, Córdoba Labor Secretariat. 2008. Interview with the Author. 24 June, Córdoba.

C36, Córdoba Labor Secretariat. 2008. Interview with the Author. 14 July, Córdoba.

C44, Senior Official, Córdoba Labor Secretariat. 2008. Interview with the Author. 26 June, Córdoba.

California Business and Professions Code Section 17200.

Castillo-Reynoso, C. (1999). Situación de Trabajo y Protección de los Trabajadores: Estudio del Caso de México. International Labour Organisation.

Chin, L. 2014. Interview with the Author. 14 August.

Chung, S. (2013). A Pluralistic, Pragmatic Approach to Labour Law Enforcement in China. Working Paper, Sogang University, South Korea. 
City Attorney Dennis Herrera News Release. (2011). Wage Theft Lawsuit Seeks to Recover $\$ 440 K$ in Back Pay, Interest for Cheated Workers. [Online] 12 July. http://www.sfcityattorney.org/ 2011/07/12/wage-theft-lawsuit-seeks-to-recover-440k-inback-pay-interest-for-cheated-workers/.

Cohen, J. \& Rogers, J. (1992). Secondary Associations and Democratic Governance. Politics \& Society. 20(4), pp. 393-472.

Collier, D. \& Mahoney, J. (1996). Insights and Pitfalls: Selection Bias in Qualitative Research. World Politics. 49(1), pp. 56-91.

Cook, Brian J., and B. Dan Wood. "Principal-agent models of political control of bureaucracy." American Political Science Review 83.03 (1989): 965-978.

Cooney, S. (2007). China's Labour Law, Compliance and Flaws in Implementing Institutions. Journal of Industrial Relations. 49(5), pp. 673-686.

Coslovsky, S., Pires, R. \& Silbey, S. (2011). The Pragmatic Politics of Regulatory Enforcement. In Levi-Faur, D. (ed.). Handbook on the politics of regulation: VIITowards Better Regulation? London: Edward Elgar Publishers.

Delp, L. \& Riley, K. (2015). Worker Engagement in the Health and Safety Regulatory Arena Under Changing Models of Worker Representation. Labor Studies Journal.

Estlund, C. (2005). Rebuilding the Law of the Workplace in an Era of Self-Regulation. Columbia Law Review. 105(2), pp. 319-404.

Fine, J. R. (2006). Worker Centers: Organizing Communities at the Edge of the Dream. New York: Cornell University Press.

Fine, J. (2014). Solving the Problem from Hell: Tripartism as a Strategy for Addressing Labour Standards Non-Compliance in the United States. Osgoode Hall Law Journal. 50(4), pp. 813-844.

Fine, J. \& Gordon, J. (2010). Strengthening Labor Standards Enforcement through Partnerships with Workers' Organizations. Politics \& Society. 38(4), pp. 552-585.

Freeman, J. (1997). Collaborative Governance in the Administrative State. UCLA Law Review. 45(1), pp. 1-77.

Freeman, J. (2000). Private Role in the Public Governance. NYU Law Review. 75(101), pp. 1109.

Fung, A. \& Wright, E.O. (2001). Deepening Democracy: Innovations in Empowered Participatory Governance. Politics \& Society. 29(1), pp. 5-41. 
Fung, A. \& Wright, E.O. (2003). Deepening Democracy: Innovations in Empowered Participatory Governance: The Real Utopias Project IV. New York: Verso Books.

George, A. \& Bennett, A. (2005). Case Studies and Theory Development in the Social Sciences. Massachusetts: MIT Press.

Gleeson, S. (2012). Conflicting Commitments: The Politics of Enforcing Immigrant Worker Rights in San Jose and Houston. New York: ILR Press.

Gleeson, Shannon. "From rights to claims: the role of civil society in making rights real for vulnerable workers." Law \& Society Review 43.3 (2009): 669-700.

Gordon, J. (2005). Suburban Sweatshops: The Fight for Immigrant Rights. Massachusetts: Harvard University Press.

Gunton, T.I. \& Day, J.C. (2003). The Theory and Practice of Collaborative Planning in Resource Management. Environments. 31(2), pp. 31-46.

Hardy, T. (2011). Enrolling Non-State Actors to Improve Compliance with Minimum Employment Standards. The Economic \& Labour Relations Review. 22(3), pp. 117-140.

Huber, G. (2007). The Craft of Bureaucratic Neutrality. New York: Cambridge University Press.

Imperial, M. (2005). Using Collaboration as a Governance Strategy: Lessons from Six Watershed Management Programs. Administration \& Society. 37(3), pp. 281-320.

International Labor Organization. (2006). Report III (Part 1B) General Survey of the reports concerning the Labour Inspection Convention. International Labour Conference, 95th Session.

Johnson, T.R. (2014). Regulatory Dynamism of Environmental Mobilization in Urban China. Regulation \& Governance.

Joshi, A. \& Moore, M. (2004). Institutionalised Co-Production: Unorthodox Public Service Delivery in Challenging Environments. Journal of Development Studies. 40(4), pp. 3149.

Kelman, S. (1981). Regulating America, Regulating Sweden: A Comparative Study of Occupational Safety and Health Policy. Massachusetts: MIT Press.

La Capital. (2006). Cuestionan a Empresas que no Cuidan a Obreros de la Construcción. 1 November.

La Capital. (2006). En un Año, 6 Albañiles Muertos y 10 Heridos. 13 March. 
La Voz del Interior. (2004). La Seguridad Laboral se Relajó. 9 March.

Levine, D., Toffel, M. \& Johnson, M. (2012). Randomized Government Safety Inspections Reduce Worker Injuries with No Detectable Job Loss. Science. 336(6083), pp. 907-911.

Levitsky, S. \& Murillo, M. (2005). Introduction. In Levitsky S. \& Murillo, M. (eds.). Argentine Democracy: The Politics of Institutional Weakness. Pennsylvania: Pennsylvania State University Press.

Levitt, D. 2014. Interviews with the Author. 11 August \& 18 August.

Lierman, B. E. (2010). To Assure Safe and Healthful Working Conditions: Taking Lessons from Labor Unions to Fulfill OSHA's Promises. Loyola University Journal of Public Interest Law. 12(1).

Liu, S. 2014. Interviews with the Author. 12 August \& 12 September.

Lobel, O. (2004). The Renew Deal: The Fall of Regulation and the Rise of Governance in Contemporary Legal Thought. Minnesota Law Review. 89(2), pp. 7-27.

Locke, R. M. \& Thelen, K. (1995). Apples and Oranges Revisited: Contextualized Comparisons and the Study of Comparative Labor Politics. Politics \& Society. 23(3), pp. 337-368.

Mann, M. (1993). The Sources of Social Power: Volume 2, The Rise of Classes and NationStates, 1760-1914. New York, Cambridge University Press.

Miller, Gary J. "The political evolution of principal-agent models." Annu. Rev. Polit. Sci. 8 (2005): 203-225.

Moe, Terry M. "The new economics of organization." American journal of political science (1984): 739-777.

Morantz, A. (2011). Does Unionization Strengthen Regulatory Enforcement-An Empirical Study of the Mine Safety and Health Administration. NYU Journal of Legislation \& Public. Policy. 14, pp. 697-727.

Morantz, A. (2013). Coal Mine Safety: Do Unions Make a Difference? Industrial \& Labor Relations Review. 66(1), pp. 88-116.

Murdock, B.S., Wiessner, C. \& Sexton, K. (2005). Stakeholder Participation in Voluntary Environmental Agreements: Analysis of 10 Project XL Case Studies. Science, Technology, \& Human Values. 30(2), pp. 223-250.

Nong, H.L., Lin, G., Shuang, L., Wen Lan, R., Xiong, M. \& Shu, Z.B. (2010). Check Please! Health and Working Conditions in San Francisco Chinatown Restaurants. A report by the Chinese Progressive Association in partnership with the San Francisco Department of 
Public Health, University of California San Francisco Medical School, University of California Berkeley Schools of Public Health and Labor Occupational Health Program. http://www.cpasf.org/sites/default/files/CPA\%20full\%20report_ENG_0.pdf.

Nordlund, W. J. (1997). The Quest for a Living Wage: The History of the Federal Minimum Wage Program. Connecticut: Greenwood Publishing Group.

O'Rourke, D. (2004). Community Driven Regulation: Balancing Development and the Environment in Vietnam. Massachusetts: MIT Press.

Ostrom, E. (1996). Crossing the Great Divide: Coproduction, Synergy, and Development. World Development. 24(6), pp. 1073-1087.

Pedriana, N. \& Stryker, R. (2004). The Strength of a Weak Agency: Enforcement of Title VII of the 1964 Civil Rights Act and the Expansion of State Capacity, 196519711. American Journal of Sociology. 110(3), pp. 709-760.

Perrow, C. (2014). Complex Organizations: A Critical Essay. Vermont: Echo Point Books \& Media.

Piore, M. \& Schrank, A. (2008). Toward Managed Flexibility: The Revival of Labour Inspection in the Latin World. International Labour Review. 147(1).

Pires, R. (2011). Beyond the Fear of Discretion: Flexibility, Performance, and Accountability in the Management of Regulatory Bureaucracies. Regulation \& Governance. 5(1), pp. 4369.

Polyani, M. (1967). The Tacit Dimension. New York: Anchor Books.

Rogers, T., Howard-Pitney, B., Feighery, E.C., Altman, D.G., Endres, J.M. \& Roeseler, A.G. (1993). Characteristics and Participant Perceptions of Tobacco Control Coalitions in California. Health Education Research. 8(3), pp. 345-357.

Ronconi, L. (2010). Enforcement and Compliance with Labor Regulations. Industrial \& Labor Relations Review. 63(4).

Ronen, H. 2014. Interview with the Author. 3 September.

Ruckelshaus, C. K. (2008). Labor's Wage War. Fordham Urban Law Journal. 35(2), pp. 373403.

Sabel, C. \& Dorf, M. (1998). A Constitution of Democratic Experimentalism. Columbia Law Review. 98(2), pp. 267-473. 
Sabel, C., Fung, A. \& O'Rourke, D. (2000). "Ratcheting Labor Standards: Regulation for Continuous Improvement in the Global Workplace". Social Protection Discussion Paper Series No. 0011.

San Francisco Administrative Code, Section 2A.23 Office of Labor Standards Enforcement.

San Francisco Administrative Code, Section 12R.25.

Schrank, A. (2013). From Disguised Protectionism to Rewarding Regulation: The Impact of Trade-Related Labor Standards in the Dominican Republic. Regulation \& Governance. 7(3), pp. 299-3

Spiller, P.T. \& Tommasi, M. (2007). The Institutional Foundations of Public Policy in Argentina. New York: Cambridge University Press.

Tushman, M. L. \& Scanlan, T. J. (1981). Boundary Spanning Individuals: Their Role in Information Transfer and Their Antecedents. Academy of Management Journal. 24(2), pp. 289-305.

Valen, T. \& Pichay, E. 2014. Interview with the Author. 12 August.

Van Rooij, B. et al. (2013). From Support to Pressure: The Dynamics of Social and Governmental Influences on Environmental Law Enforcement in Guangzhou City, China. Regulation \& Governance. 7(3), pp. 321-347.

Weech-Maldonado, R. \& Merrill, S.B. (2000). Building Partnerships with the Community: Lessons from the Camden Health Improvement Learning Collaborative. Journal of Healthcare Management/American College of Healthcare Executives. 45(3), pp. 189205.

Weil, D. (1991). Enforcing OSHA: The Role of Labor Unions. Industrial Relations: A Journal of Economy and Society. 30(1), pp. 20-36.

Weil, D. (1992). Building safety: The Role of Construction Unions in the Enforcement of OSHA. Journal of Labor Research. 13(1), pp. 121-132.

Weil, D. (1996). If OSHA is So Bad, Why is Compliance So Good? The RAND Journal of Economics. 27(3), pp. 618-640.

Weil, D. (2010). Improving Workplace Conditions Through Strategic Enforcement: A Report to the Wage and Hour Division. [Online] US Department of Labor. pp. 18-26 http://www.dol.gov/whd/resources/strategicEnforcement.pdf.

Weil, D. (2014). The Fissured Workplace. Massachusetts: Harvard University Press.

Weil, D. \& Pyles, A. (2005). Why Complain-Complaints, Compliance, and the Problem of Enforcement in the US Workplace. Comparative Labor Law \& Policy Journal. 27(59). 
Weiss, L. (1998). The Myth of the Powerless State. New York: Cornell University Press.

Wilson, J. (1982). The Politics of Regulation. New York: Basic Books Publishing. Yu, K. 2014. Interview with the Author. 13 August.

${ }^{[1]}$ Exceptions include: Fine and Gordon, 2010; Fine, 2014; Gleeson, 2012.

${ }^{[2]}$ Where confidentiality was required, interviews are identified by a code.

${ }^{[3]}$ This section builds on a broader analysis of Argentine enforcement in Amengual 2016.

${ }^{[4]}$ For example, in the neighboring and similar size city of Rosario, inspectors reached only 30 worksites a month in 2006 while Córdoba inspectors averaged 190 a month.

${ }^{[5]}$ The firms are required to continue paying workers in these cases, and reportedly they often do.

${ }^{[6]}$ In addition, one author observed health and safety inspections of construction sites during which inspectors interacted with managers from firms.

${ }^{[7]}$ Calculated from a combination of employment data from the Obra Social del Personal de la Construcción and deaths in the industry from the STC and SRT. Using these numbers, it appears that deaths have fallen (in 2002, there were 3.6 deaths per 1,000 workers, while in 2007 there were only 0.3 ). 